\title{
Characterization of endothelin-1 and nitric oxide generating systems in corpus luteum-derived endothelial cells
}

\author{
Eyal Klipper, Tamar Gilboa, Nitzan Levy, Tatiana Kisliouk, Katharina Spanel-Borowski ${ }^{1}$ and \\ Rina Meidan
}

Department of Animal Sciences, Faculty of Agricultural, Food and Environmental Quality Sciences, The Hebrew University of Jerusalem, Rehovot 76100, Israel and ${ }^{1}$ Institute of Anatomy, University of Leipzig, Liebigstrasse 13, D-04103, Leipzig, Germany

Correspondence should be addressed to R Meidan; Email: rina.meidan@huji.ac.il

\begin{abstract}
Endothelium-derived endothelin-1 (ET-1) and nitric oxide (NO) are pivotal regulators of corpus luteum (CL) function. To have a better insight into their synthesis and action, members of the ET system (ET-1, ET converting enzyme (ECE-1) isoforms a-d, $\mathrm{ET}_{\mathrm{A}}$ and $\mathrm{ET}_{\mathrm{B}}$ receptors) along with $\mathrm{NO}$ synthase (NOS) isoforms - endothelial (e)NOS and inducible (i)NOS - were quantified in CL-derived endothelial cells (CLEC). The expression of these genes in microvascular CLEC, obtained by lectin-coated magnetic beads, was compared with cells removed from the luteal microenvironment and maintained in culture for different durations, and with endothelial cells (EC) derived from a large blood vessel (i.e. bovine aortic endothelial cells, BAEC). The profile of gene expression in the different EC types was determined by quantitative real-time PCR. Freshly isolated EC from mid-cycle CL exhibited high ET-1 receptor expression (both $\mathrm{ET}_{\mathrm{A}}$ and $\mathrm{ET}_{\mathrm{B}}$ ), low ET-1 synthesizing ability (both prepro (pp) ET-1 and ECE-1), but elevated iNOS - the high throughput NOS isoform. The distinct phenotype of CLEC was lost soon after an overnight culture. $\mathrm{ET}_{A}$ and $\mathrm{ET}_{B}$ receptor levels declined, ppET-1 levels increased while iNOS was reduced. These changes were extenuated during long-term culture of CLEC. The general pattern of gene expression in BAEC and long-term cultured CLEC was similar yet some differences, reminiscent of freshly isolated CLEC, remained: ECE-1C, $E_{B}$ receptor and NOS isoforms were expressed differently in BAEC as compared with lines of CLEC.

This study suggests that the luteal microenvironment is necessary to sustain the selective phenotype of its resident endothelial cells. The inverse relationship between ppET-1 and iNOS observed in freshly isolated CLEC and in cultured cells is physiologically significant and suggests that ET-1 and NO may modulate the production of each other.

Reproduction (2004) 128 463-473
\end{abstract}

\section{Introduction}

The corpus luteum is a highly vascular endocrine gland endowed with one of the highest blood flows in the adult organism. The dense network of blood capillaries irrigating the corpus luteum allows an intricate cross talk between luteal steroidogenic and endothelial cells (Grazul Bilska et al. 1997, Reynolds et al. 2000). Endotheliumderived compounds, endothelin-1 (ET-1) and nitric oxide $(\mathrm{NO})$, have been demonstrated to play pivotal roles in corpus luteum function. These vasoactive compounds inhibit progesterone production and it has been proposed that they act as mediators during the process of luteolysis (Miyamoto et al. 1997, Meidan et al. 1999, Jaroszewski \& Hansel 2000, Skarzynski \& Okuda 2000, Hinckley \& Milvae 2001). The microvascular system is locally specialized to accommodate the needs of individual tissues, and endothelial cells lining these blood vessels exhibit distinct gene expression profiles (Chi et al. 2003). Therefore, understanding the characteristics of microvascular luteal endothelial cells may lead to a better insight into corpus luteum physiology.

ET-1 and NO are produced within the corpus luteum; however the characteristic profiles of ET-1 and NO generating systems in corpus luteum-derived microvascular cells are unknown. The formation of $\mathrm{NO}$ from L-arginine is catalyzed by several NO synthase (NOS) isoenzymes (Alderton et al. 2001, Albrecht et al. 2003). Endothelial cells were shown to contain a constitutive isoform, designated endothelial (e)NOS, and an inducible (i) isoform, iNOS. The constitutive isoform, eNOS, contributes a low NO output, while iNOS, induced by a variety of inflammatory cues, produces much higher levels of NO. The ET system encodes a family of signaling peptides, G-protein-coupled 
receptors $\left(\mathrm{ET}_{\mathrm{A}}\right.$ and $\mathrm{ET}_{\mathrm{B}}$ ) and converting enzymes (ECE) which are expressed in the ovaries of several domestic animal species (Mamluk et al. 1999, Wright et al. 2001, Meidan \& Levy 2002). ET-1 is produced as a large prepro (pp) endothelin polypeptide of $\sim 200$ amino acids. Following removal of the signal peptides, the inactive intermediate, big ET, consisting of 38-41 amino acids is formed (Schmidt et al. 1994, Xu et al. 1994). ECE-1 then cleaves big ET between Trp21 and Val22/lle22 to generate the mature, active 21-amino acid peptide (Schmidt et al. 1994, Xu et al. 1994). The importance of this cleavage site is demonstrated by the fact that the vasoconstricting activity of either ET-1 (1 -20) amino acids or ET-1 (1-22) amino acids is three orders of magnitude weaker than ET-1 (1-21) amino acids (Okada et al. 1990). Four isoforms of ECE-1 (1a, 1b, 1c, and 1d) have been identified (Schweizer et al. 1997, Turner et al. 1998, Valdenaire et al. 1999b). The four proteins are encoded by one gene and share a common carboxyl-terminal portion. Each is expressed from a distinct promoter that regulates expression of four unique amino termini (Turner et al. 1998, Valdenaire et al. 1999b). Although the ectodomain containing the active site is identical in each of the isoforms, the diverse aminoterminal sequences may be responsible for differences in subcellular localization, directing different intracellular sites for ET-1 production (Turner et al. 1998, Emoto et al. 1999, Valdenaire et al. 1999b). ET-1 acts via two G-protein-coupled receptors termed $\mathrm{ET}_{\mathrm{A}}$ and $\mathrm{ET}_{\mathrm{B}}$ (Arai et al. 1990, Aramori \& Nakanishi 1992) mediating its diverse biological responses (Neylon 1999).

This study was designed to characterize the expression of the ET-1 system and NOS isoforms in corpus luteumderived microvascular endothelial cells using freshly isolated cells obtained by lectin-coated magnetic beads. To better characterize the phenotype of luteal endothelial cells, we compared their expression profile with cells removed from the luteal microenvironment and maintained in culture for different durations and also with endothelial cells derived from a large blood vessel (i.e. bovine aortic endothelial cells, BAEC).

\section{Materials and Methods}

\section{Materials}

M-199 nutrient mixture, Dulbecco's Minimum Essential Medium (DMEM) with Ham's F12 1:1 (v/v) nutrient mixture, SuperScriptll RNase $\mathrm{H}^{-}$reverse transcriptase, calf serum (CS) and Ultra pure electrophoresis agarose gel were from Gibco BRL Life Technologies (Gaithersburg, MD, USA). Vitrogen, type I collagen, was from Cohesion Technologies (Palo Alto, CA, USA). Bandeiraea simplicifolia lectin-1 (BS-1) was from Vector Laboratories (Burlingame, CA, USA). Collagenase type IV was from Worthington Biochemical Corp. (Freehold, NJ, USA). Uncoated magnetic beads (Dynabeads M-450) were from Dynal (Oslo, OM, Norway). Penicillin, streptomycin, and fetal calf serum (FCS) were from Biological Industries (Beit Haemek, Israel). Deoxynucleotide triphosphates, random hexamer oligodeoxynucleotides, and Taq DNA polymerase were from Fermentas (Vilnius, Lithuania). Oligo-dT and oligonucleotide primers were synthesized by MWG Biotech AG (Ebersberg, Germany). Real-time PCR SYBR Green master-mix kit was from Eurogentec (Seraing, Belgium). Rabbit anti-human von Willebrand factor antibody was from Dako (Glostrup, Denmark). Cy3-conjugated donkey anti-rabbit IgG fluorescent antibody was from Jackson (West Grove, PA, USA). Protease inhibitor cocktail for mammalian cell extracts and horseradish peroxidaseconjugated goat anti-rabbit IgG were from Sigma (St Louis, MO, USA). Rabbit anti-ET $\mathrm{E}_{\mathrm{A}}$ and anti-ET $\mathrm{E}_{\mathrm{B}}$ were from Alomone Labs (Jerusalem, Israel). Protein quantification kit was from Bio-Rad Laboratories (Hercules, CA, USA).

\section{Corpus luteum collection, luteal cell dispersion and endothelial cells enrichment}

Corpora lutea were collected at a local slaughterhouse and the luteal stage was determined by macroscopic examination, as described by Fields and Fields (1996). Corpora lutea at the mid-luteal phase (day 9-14) were dispersed using collagenase as previously described (Levy et al. 2001, 2003). Briefly, corpora lutea were washed, sliced with a tissue slicer, and preincubated in a shaking bath at $37^{\circ} \mathrm{C}$ for $10 \mathrm{~min}$ in $\mathrm{M}-199$. Slices were then incubated in M-199 containing 0.5\% BSA and collagenase $(420 \mathrm{U} / \mathrm{ml})$. Every $10 \mathrm{~min}$, dissociated cells were removed, and fresh media containing collagenase were added. This procedure was repeated 8-10 times. Dissociated cells were kept in media containing 5\% FCS until the end of the procedure. Magnetic tosylactivated beads were coated with BS-1 lectin $(0.15 \mathrm{mg} / \mathrm{ml})$ which specifically binds glycoproteins expressed by bovine endothelial cells. Dispersed luteal cells were suspended in 1\% BSA in M-199, mixed with beads and incubated for $25 \mathrm{~min}$ at $4{ }^{\circ} \mathrm{C}$ on a rocking platform. The adherent cells (BS-1 positive) were washed with M-199 containing 1\% BSA and concentrated using a magnet until the supernatant was free of BS-1 negative cells. The adherent cells were subsequently eluted by $0.2 \mathrm{M}$ lactose solution in PBS. Enriched endothelial cells were seeded on plates pre-coated with Vitrogen $(2 \%)$ and cultured overnight in DMEM Ham's F12 containing $10 \%$ FCS. Freshly isolated (dispersed) and cultured endothelial cells were collected for RNA extraction.

\section{Long-term endothelial cell cultures}

BAEC were kindly provided by I Vlodavsky of the Hadassah-Hebrew University Hospital, (Jerusalem, Israel). These cells were grown in complete DMEM low-glucose medium containing $10 \%$ calf serum and $2 \mathrm{mM}$ glutamine. Cytokeratin-positive $(\mathrm{CK}+)$ and cytokeratin-negative $(\mathrm{CK}-)$ endothelial cells (EC) derived from the bovine corpus luteum (Spanel Borowski \& van der Bosch 1990, Spanel Borowski \& Bein 1993, Spanel Borowski \& Fenyves 
1994) were used. These cell types maintain a stable phenotype during culture, and differ in morphological appearance, intercellular adhesion molecules, angiogenic genes and in the ability to form capillary-like structures. These cells were grown on plates pre-coated with $2 \%$ Vitrogen in complete DMEM Ham's F12 containing 10\% FCS and $2 \mathrm{mM}$ glutamine. Experiments were carried out on cells from passages 5 to 12 , with $70-80 \%$ confluence.

\section{RNA extraction and RT-PCR}

Total RNA was extracted from cells (dispersed and cultured) by tri-reagent. One microgram total RNA was reverse transcribed in a total volume of $20 \mu$ l using $200 \mathrm{U}$ reverse transcriptase, $50 \mathrm{pmol}$ random hexamer and $0.075 \mathrm{nmol}$ oligo-dT. Semi-quantitative PCR was performed as described before with the housekeeping gene glyceraldehyde-3phosphate dehydrogenase (G3PDH) used as an internal standard (Mamluk et al. 1999). The sequences of the primers used in the PCR reactions are shown in Table 1.

\section{Real-time PCR}

PCR reactions were performed using the PE Biosystems (Foster City, CA, USA) GeneAmp 5700 sequence detection system using the SYBR Green I PCR kit. Standard curves of sample cDNA were generated using serial dilutions (1:2 to $1: 100)$. In initial experiments, PCR product identities were verified by agarose gel electrophoresis and DNA sequencing. Real-time PCR master mix reaction contained $12.5 \mu \mathrm{l}$ of the $2 \times$ SYBR Green buffer containing ROX passive reference, $200 \mu \mathrm{M}$ dNTPs including dUTP, $5 \mathrm{mM}$ $\mathrm{MgCl}_{2}$, uracil $\mathrm{N}$-glycosylase and Amplitaq HotGoldStar DNA polymerase, 0.55 pmol forward and reverse primers (list of real time PCR primers is shown in Table 2), $0.75 \mu \mathrm{l}$ of a 1:10000 dilution of SYBR Green stock solution and $1 \mu \mathrm{l}(1 \mu \mathrm{g} / \mu \mathrm{l}) \mathrm{cDNA}$ in a total volume of $25 \mu \mathrm{l}$. The reactions were performed in $0.2 \mathrm{ml}$ PCR tubes capped with Micro-Amp optical caps. The reactions were incubated at $95^{\circ} \mathrm{C}$ for 10 min to activate the Amplitaq Gold polymerase, followed by 40 cycles of $15 \mathrm{~s}$ at $95^{\circ} \mathrm{C}$ for denaturation and $1 \mathrm{~min}$ at $60^{\circ} \mathrm{C}$ for both annealing and elongation. The PCR reactions were subjected to a heat dissociation protocol present in the PE Biosystems 5700 software to monitor PCR product purity. Relative expression of the RT-PCR products was determined using the $\Delta \Delta C_{t}$ method (Livak \& Schmittgen 2001). This method calculates relative

Table 1 Primers used in semi-quantitative PCR.

\begin{tabular}{|c|c|c|c|}
\hline Gene & Primer & Sequence & $\begin{array}{l}\text { Product } \\
\text { length }(b p)\end{array}$ \\
\hline G3PDH & $\begin{array}{l}\text { Forward } \\
\text { Reverse }\end{array}$ & $\begin{array}{l}\text { 5'-TGTTCCAGTATGATTCCACCC-3' } \\
5^{\prime} \text { - TCCACCACСCTGTTGCTGTA-3' }\end{array}$ & 850 \\
\hline CD-31 & $\begin{array}{l}\text { Forward } \\
\text { Reverse }\end{array}$ & $\begin{array}{l}5^{\prime}-\text { TGAGGAGCAAGACCGTACCATA-3' } \\
5^{\prime}-\text { ACGGAGCAGTAAAACACAATGG }-3^{\prime}\end{array}$ & 987 \\
\hline Tie-2 & $\begin{array}{l}\text { Forward } \\
\text { Reverse }\end{array}$ & $\begin{array}{l}5^{\prime}-\text { CCAGTGTGAGAAAGAAGGTGT-3' } \\
5^{\prime}-\text { CCGTCCGAGGCTCCAAATAG-3' }\end{array}$ & 523 \\
\hline
\end{tabular}

www.reproduction-online.org
Table 2 Primers used in real-time PCR.

\begin{tabular}{|c|c|c|c|}
\hline Gene & Primer & Sequence & $\begin{array}{c}\text { Product } \\
\text { length (bp) }\end{array}$ \\
\hline \multirow[t]{2}{*}{ G3PDH } & Forward & 5'-GGCGTGAACCACGAGAAGTAT-3' & 141 \\
\hline & Reverse & 5'-CGTGGACAGTGGTCATAAGT-3' & \\
\hline \multirow[t]{2}{*}{ ECE-total } & Forward & 5'-TGTGGCGGCTGGATCAAAGC-3' & 103 \\
\hline & Reverse & 5'-AGGTGCTTGATGATGGCTTG-3' & \\
\hline \multirow[t]{2}{*}{ ECE-1a } & Forward & 5'-GTTCCTCTCCTGGATTAG-3' & 178 \\
\hline & Reverse & 5'-CTTGTCTGGTATTGGATGC-3' & \\
\hline ECE-1b & Forward & 5'-TGTCGGTGGGGATGTC-3 & 113 \\
\hline ECE-1C & Forward & 5'-CGGAGCGCGCGAGCGAT-3' & 109 \\
\hline ECE-1d & Forward & 5'-CCATGGAGGCGCTAAGAGAGT-3' & 142 \\
\hline $\begin{array}{c}\text { ECE } 1 b ; \\
\quad c ; d\end{array}$ & Reverse & 5'-GAAGTTCACCTGCAGGTGGT-3' & \\
\hline \multirow[t]{2}{*}{ ET-1 } & Forward & 5'-TGTCTTCATCAGCAGCTC-3' & 98 \\
\hline & Reverse & 5'-TCAGCTTGGCAACACGAA-3' & \\
\hline \multirow[t]{2}{*}{$\mathrm{ET}_{\mathrm{a}}$} & Forward & $5^{\prime}-$ TACCAGAACAAGTGCATGAG-3' & 194 \\
\hline & Reverse & 5'-CACTGAGGACTTCTGCAA-3' & \\
\hline \multirow{2}{*}{$\mathrm{ET}_{\mathrm{b}}$} & Forward & 5'-AAGTACATCAACACGGTGGT-3' & 194 \\
\hline & Reverse & 5'-GGCAAGCAGCTTGTAGGTAT-3' & \\
\hline \multirow[t]{2}{*}{ iNOS } & Forward & 5'-GGTGGAAGCAGTAACAAAGGA-3' & 235 \\
\hline & Reverse & 5’ GACCTGATGTTGCCGTTGTTG-3' & \\
\hline \multirow[t]{2}{*}{ eNOS } & Forward & 5'-ССТСАССGСТАСАAТАТССТ-3' & 199 \\
\hline & Reverse & 5'-TGCTCGTTGTCCAGGTGCTTC-3' & \\
\hline
\end{tabular}

expression using the equation: fold induction $\left.=2^{-\left[\Delta \Delta C_{t}\right.}\right]$, where $\mathrm{C}_{t}=$ the threshold cycle, i.e. the cycle number at which the sample's relative fluorescence increases above the background fluorescence and $\Delta \Delta C_{t}=\left[C_{t}\right.$ gene of interest (unknown sample) $-\mathrm{C}_{t} \quad \mathrm{G} 3 \mathrm{PDH}$ (unknown sample) $]-\left[C_{t}\right.$ gene of interest (calibrator sample) $-C_{t}$ G3PDH (calibrator sample)]. Each sample was run in duplicate and the mean $C_{t}$ was used in the $\Delta \Delta C_{t}$ equation. For each data set the calibrator chosen was the one with the lowest expression.

\section{Factor-VIII staining}

Long-term cultured endothelial cells (CK-EC), BAEC and isolated luteal endothelial cells after overnight culture were fixed in methanol $\left(4^{\circ} \mathrm{C}, 5 \mathrm{~min}\right)$ and subsequently washed 3 times with PBS. After 45 min blocking with $2 \%$ gelatin at room temperature, cells were incubated with rabbit anti-human von Willebrand factor (factor VIII endothelial cell marker) for $2 \mathrm{~h}$. The cells were washed, and then incubated with Cy3-conjugated donkey anti-rabbit IgG fluorescent antibody for $1 \mathrm{~h}$ and washed again. Cells were photographed using a fluorescent microscope (magnification $\times 640,543 \mathrm{~nm}$ ).

\section{Western blot analyses}

The procedure was carried out as previously described (Levy et al. 2001). Endothelial cells (dispersed and cultured) were homogenized in lysis buffer $(25 \mathrm{mM}$ Tris $\mathrm{HCl}$, $100 \mathrm{mM} \mathrm{NaCl}, 0.5 \%$ deoxycholate, $0.5 \% \mathrm{NP} 40,5 \mathrm{mM}$ EDTA at $\mathrm{pH} 7.5$ and protease inhibitor cocktail) and were immediately sonicated on ice for $2 \mathrm{~min}$. Homogenates were centrifuged for $1 \mathrm{~min}$ at $2000 \mathrm{~g}$ and the protein concentration of the supernatant was determined using Bio-Rad DC reagents. Samples containing $30 \mu \mathrm{g}$ protein 
were separated by $7.5 \%$ SDS/PAGE under reducing conditions and were electrically transferred to nitrocellulose membranes. After 2-h blocking in Tris-buffered salineTween-20 $+5 \%$ casein, membranes were incubated with the respective antibodies - anti ECE-1, $\mathrm{ET}_{\mathrm{A}}$ and $\mathrm{ET}_{\mathrm{B}}$ - for $2 \mathrm{~h}$. Anti-ECE-1 antiserum, produced in our laboratory, was raised against a synthetic C-terminal peptide of ECE-1 and affinity purified using the immunizing peptide immobilized on a Sepharose 4B column. The membranes were washed, and then incubated with horseradish peroxidase-conjugated goat anti-rabbit IgG for $1 \mathrm{~h}$ at room temperature, and binding was detected with an enhanced chemiluminescence detection system (Amersham Biosciences).

\section{Statistical analysis}

The data are presented as means \pm S.E.M. Data on dispersed and overnight cultured luteal endothelial cells were from four different corpora lutea and data on longterm cultured cells were from three to four different batches of each cell type used (BAEC, CK + and CK luteal endothelial cells). The differences between cell types were analyzed by one-way ANOVA, employing the post hoc multiple comparisons Dunnett's test. Analysis was performed using SPSS (SPSS Inc., Chicago, IL, USA, v 10.05 for Windows). Differences were considered significant if $P \leq 0.05$.

\section{Results}

\section{Endothelial cell markers: CD-31, Tie-2 and factor VIII}

Endothelial cell markers, CD-31 and Tie-2 - the tyrosine kinase receptor for angiopoietins - were used to identify cells utilized in this study as endothelial cells (Fig. 1). All cell types expressed high levels of CD-31 and Tie-2 mRNA except CK + EC which, as reported before (Lehmann et al. 2000), exhibited lower expression. The identification of freshly isolated luteal endothelial cells was further confirmed by the imunofluorescence staining for von Willerband factor (factor VIII; Fig. 1); these cells showed typical factor VIII staining as did luteal CK-EC (Fig. 1) and BAEC (data not shown).

\section{Expression of $E T_{A}$ and $E T_{B}$ in corpus luteum-derived endothelial cells and BAEC}

We first determined the patterns of $\mathrm{ET}_{\mathrm{A}}$ and $\mathrm{ET}_{\mathrm{B}} \mathrm{mRNA}$ levels in different corpus luteum-derived endothelial cells and compared them with BAEC using real-time PCR (Fig. 2A, B). Interestingly, both receptor types were highly expressed in freshly isolated luteal endothelial cells. An overnight culture significantly reduced ET receptor levels, with the decline in $\mathrm{ET}_{\mathrm{B}}$ being more pronounced than that in $\mathrm{ET}_{\mathrm{A}}$ (four- vs twofold reduction respectively, $P<0.05$ ). Lower levels of $\mathrm{ET}_{\mathrm{A}}$ and $\mathrm{ET}_{\mathrm{B}}$ expression were present in long-term cultured corpus luteum-derived endothelial cells $(\mathrm{CK}+$ and $\mathrm{CK}-$ respectively; Fig. 2). In contrast,

Reproduction (2004) 128 463-473 neither $\mathrm{ET}_{\mathrm{A}}$ nor $\mathrm{ET}_{\mathrm{B}}$ mRNA could be detected in BAEC. Taken together, these data demonstrate that ET receptors are not maintained in culture. A similar pattern of $E T_{A}$ and $\mathrm{ET}_{\mathrm{B}}$ receptors was also apparent at the protein level (Fig. 2C). Freshly isolated luteal endothelial cells exhibited the highest levels of both $\mathrm{ET}_{\mathrm{A}}$ and $\mathrm{ET}_{\mathrm{B}}$ receptor protein as compared with $\mathrm{CK}-$ and $\mathrm{CK}+$ cells, while $\mathrm{ET}_{\mathrm{A}}$ could not be detected in either $\mathrm{CK}-$ or $\mathrm{CK}+$ cells or BAEC (data not shown). In contrast, although lower than the amount present in dispersed endothelial cells, $\mathrm{ET}_{\mathrm{B}}$ protein could be detected in the typical luteal endothelial cells (CK - cells). These differences are probably caused by different affinities of anti-ET receptor antibodies.

\section{Relative mRNA expression of ppET-1 and total ECE-1 in different endothelial cell types}

BAEC, CK- cells and overnight cultured luteal endothelial cells uniformly exhibited high ppET-1 mRNA expression (Fig. 3), whereas levels in freshly isolated endothelial cells were considerably lower $(27.46 \pm 2.94$ and $6.68 \pm 1.38$ for cultured endothelial cells and dispersed endothelial cells respectively; Fig. 3), indicating that ppET-1 is upregulated during culture regardless of its length.

Using primers spaning the common region of all ECE-1 forms, we found that long-term cultured cells, in spite of their origin - namely CK-EC and BAEC - both demonstrated the highest ECE-1 mRNA levels (Fig. 4) as also observed for ppET-1 (Fig. 3). Also, similar to ppET-1, freshly dispersed endothelial cells had lower levels of ECE-1 than either CK-EC or BAEC (Figs 3, 4A). However, in contrast to ppET-1, ECE-1 mRNA decreased after an overnight culture $(16.94 \pm 3.10$ and $5.96 \pm 1.61$ in freshly dispersed endothelial cells before and after overnight culture respectively; Fig. 4). ECE-1 protein in endothelial cells is depicted in Fig. 4B. The two bands represent different glycosylation patterns of the enzyme (Xu et al. 1994). In agreement with its gene expression, the highest protein levels of ECE-1 were found in CK cells and BAEC, while dispersed endothelial cells (cultured and non-cultured) and $\mathrm{CK}+$ cells exhibited low ECE-1 protein levels (Fig. 4B).

\section{Relative $m R$ RA levels of ECE-1 isoforms in corpus luteum-derived endothelial cells and BAEC}

To have a better insight of the ET-1 generating system, we examined the relative levels of each ECE-1 isoform in the various endothelial cell types (Fig. 5). All ECE-1 isoforms were present in the various endothelial cell types but their abundance differed. Although the pattern of their expression was similar, some differences could be observed: ECE-1d and $-1 \mathrm{~b}$ were highest in CK-EC and BAEC, however, a clear disparity between these two cell types was observed in terms of isoform ECE-1c expression and to a lesser extent in ECE-1a. Of the different cell types examined, BAEC expressed the highest levels of ECE-1c. $\mathrm{CK}+$ cells had relatively high ECE-1c levels, while all 


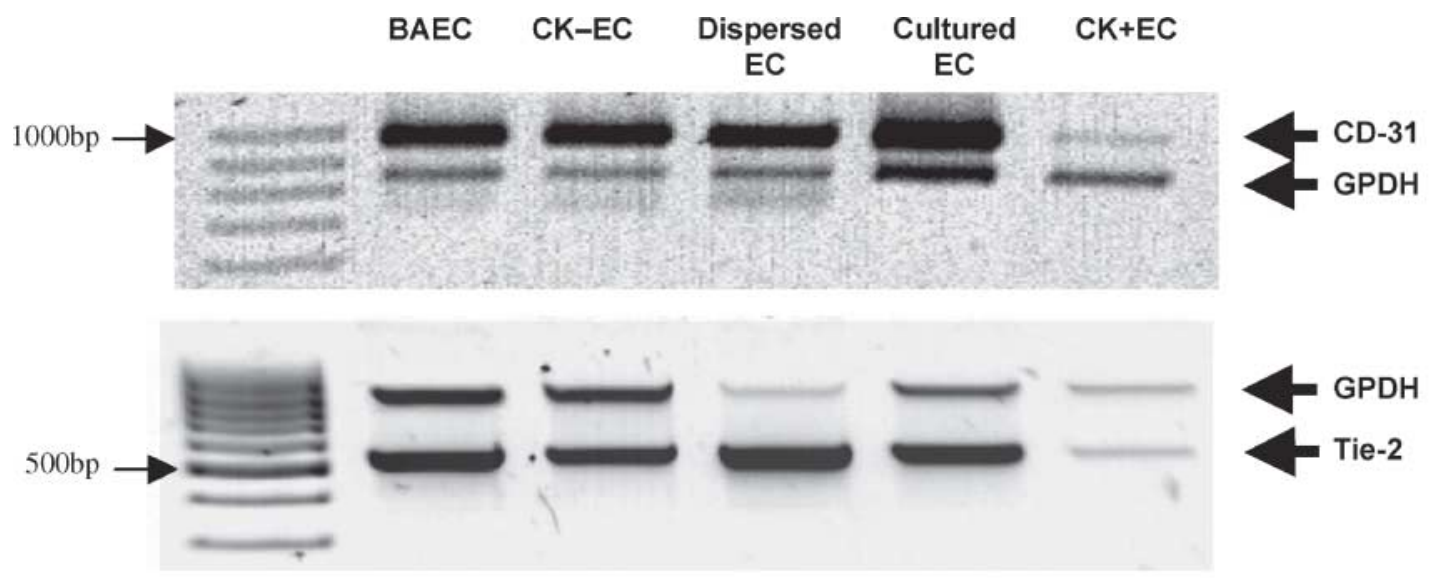

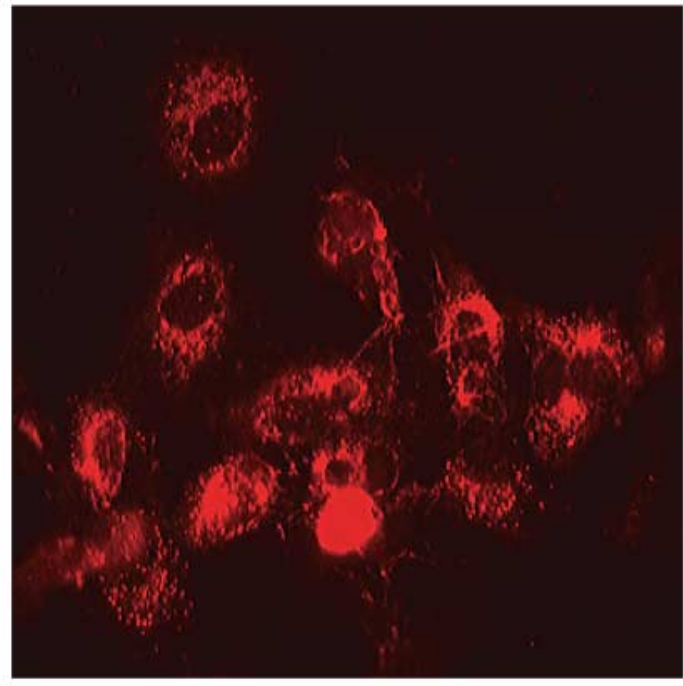

Overnight cultured EC

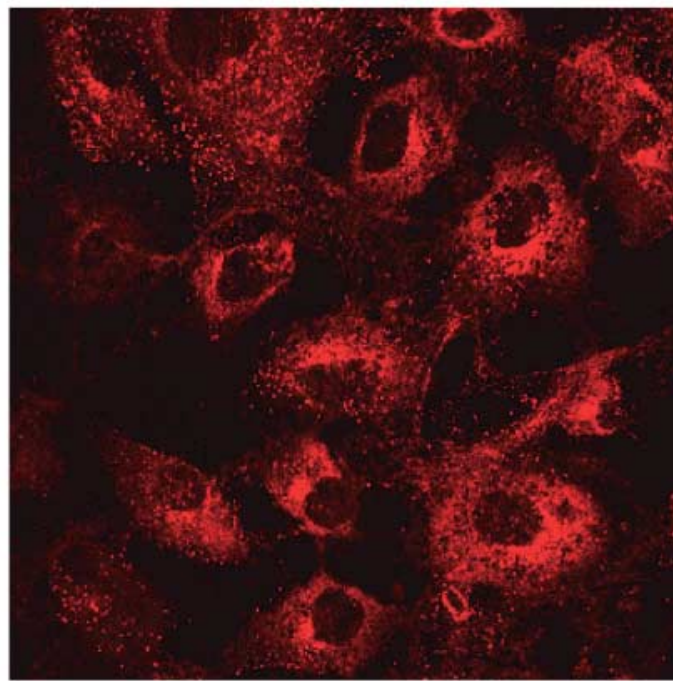

CK-EC

Figure 1 Endothelial cell (EC) identification by CD31 and Tie-2 mRNA expression (upper panel) and immunofluorescent staining for von Willebrand factor (factor VIII; lower panel). (Upper panel) Inverse images of ethidium bromide-stained agarose gel show amplification of Tie-2 and CD31 mRNA by RT-PCR with G3PDH as an internal standard. (Lower panel) Immunofluorescent staining for factor VIII in overnight cultured luteal endothelial cells and CK- endothelial cells showing a distinctive granular appearance (magnification $\times 640 ; 543 \mathrm{~nm}$ ).

other isoforms in this cell type were low compared with the other cell types. Levels of ECE- $1 \mathrm{a},-1 \mathrm{~b}$ and $-1 \mathrm{c}$ in luteal endothelial cells were not different before and after overnight culture. ECE-1d, on the other hand, the isoform which appeared to be highly expressed, fell significantly in cultured cells as compared with the dispersed cells, suggesting that reduction of this isoform may be responsible for the decline in total ECE-1 observed in these cells. In fact the pattern of ECE-1d (Fig. 5) in the various cell types was similar to that of total ECE-1 (Fig. 4).

\section{Relative mRNA levels of NOS isoforms in corpus luteum-derived endothelial cells and BAEC}

Endothelial cells freshly isolated from the corpus luteum had the highest levels of iNOS expression as compared with long-term cultured endothelial cells, luteal or aortic endothelial cells (Fig. 6), but even an overnight culture reduced iNOS expression tenfold. An opposite pattern was observed for eNOS expression: highest levels were expressed by long-term cultured CK- cells and BAEC, while freshly dispersed cells had much lower levels of expression (approx. fivefold less than in long-term cultured cells; Fig. 6).

When eNOS expression was depicted relative to that of iNOS (where iNOS served as calibrator; Fig. 7), it became clear that eNOS was the predominant form, with levels ranging from 2 and 5 in freshly isolated cells and in cells cultured overnight respectively, to an excess in eNOS of a 3 to 4 times order of magnitude in the long-term cultured cells. This also demonstrated that eNOS and iNOS are inversely regulated during culture: the constitutive type, eNOS, is upregulated, while the inducible type, iNOS, disappears almost completely. A difference in NOS isoform expression in CK-EC and 
A

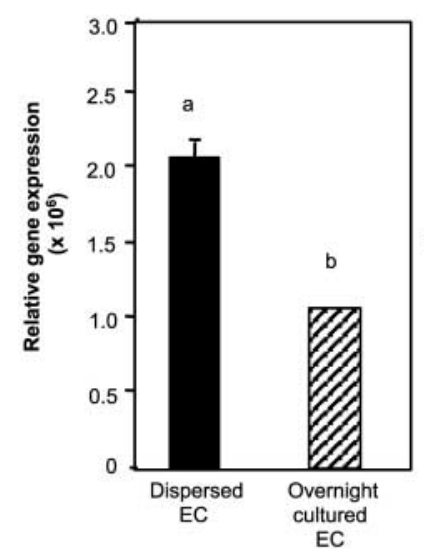

ETA
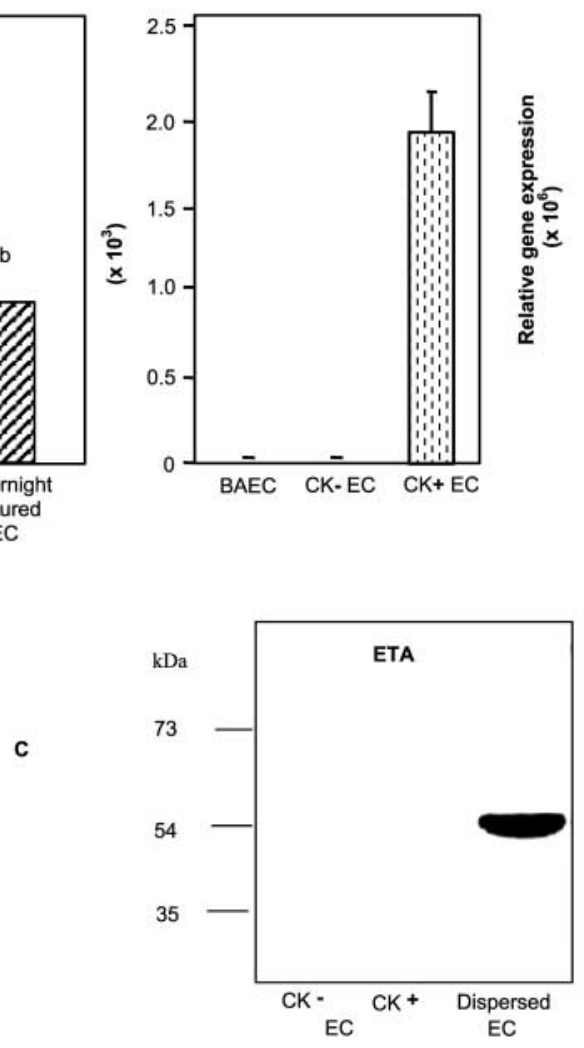

B
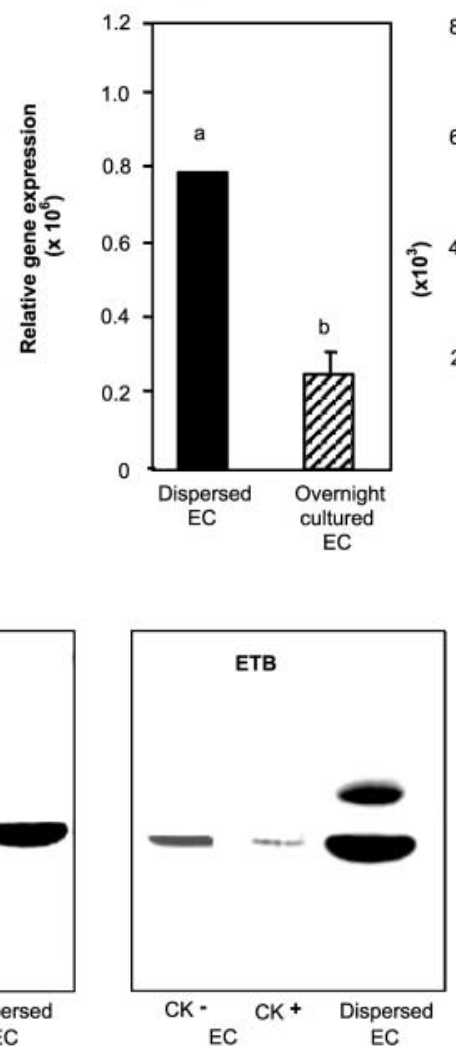

Figure 2 Characterization of $\mathrm{ET}_{\mathrm{A}}(\mathrm{ETA})$ and $\mathrm{ET}_{\mathrm{B}}(\mathrm{ETB})$ receptor mRNA expression ( $\mathrm{A}$ and $\mathrm{B}$ ) in dispersed and overnight cultured endothelial cells (EC; left panel) and long-term cultured $\mathrm{EC}$ (right panel). Data of $\mathrm{ET}_{\mathrm{A}}(\mathrm{A})$ and $\mathrm{ET}_{\mathrm{B}}(\mathrm{B})$ are the means \pm S.E.M. from three different separate experiments. Following real-time RT-PCR, relative mean mRNA levels for each cell type were calculated using the $\Delta \Delta C_{t}$ method (see Materials and Methods). Expression is normalized with G3PDH and presented as relative gene expression. Different letters indicate significant differences among cell types $(P<0.05)$. (C) $\mathrm{ET}_{\mathrm{A}}$ and $\mathrm{ET}_{\mathrm{B}}$ protein levels were determined in dispersed luteal $\mathrm{EC}, \mathrm{CK}+\mathrm{EC}$ and $\mathrm{CK}-\mathrm{EC}$ by Western blot analysis using specific antibodies. A representative Western blot is shown.

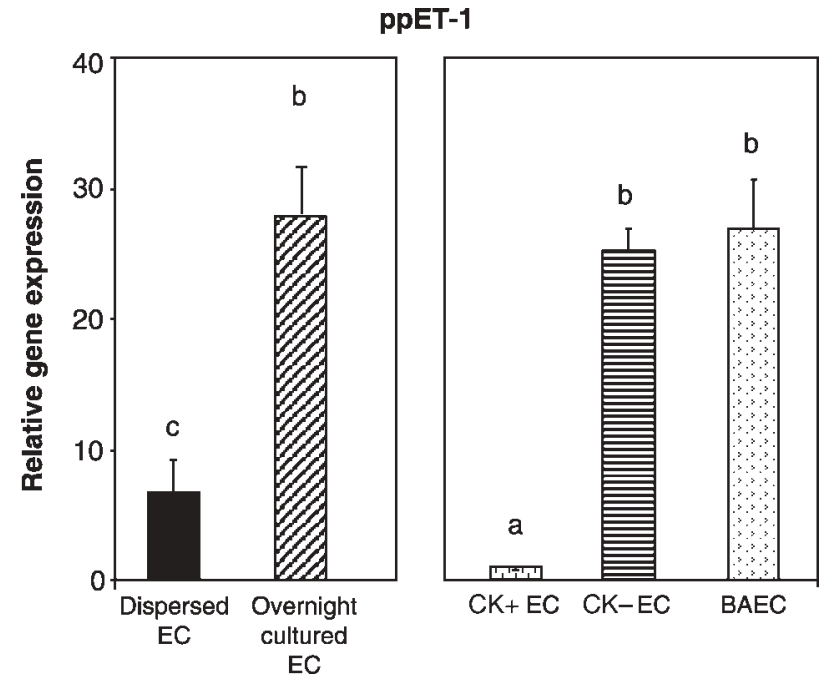

Figure 3 ppET-1 mRNA expression in dispersed and overnight cultured endothelial cells (EC; left panel) and long-term cultured EC (right panel). Results are the means \pm S.E.M. from three different experiments. For details see legend to Fig. 2. Different letters indicate significant differences among cell types $(P<0.05)$.
BAEC was noted: corpus luteum-derived cells had higher iNOS and lower eNOS than aortic-derived endothelial cells (Figs 6 and 7).

\section{Relative mRNA levels of NOS isoforms and ppET-1 in luteal steroidogenic and endothelial cells}

The corpus luteum is a heterogeneous gland comprised mainly of endothelial ( $>50 \%$ of total cells) and luteal steroidogenic $(\sim 30 \%)$ cells. To determine the cellular site of NOS isoforms and ppET-1 mRNA expression within the gland, these genes were quantified in enriched endothelial and steroidogenic cell types (Levy et al. 2001) using real-time PCR. Data presented in Table 3 demonstrate that iNOS, eNOS and ppET-1 were expressed in orders of magnitude one or two times higher in endothelial cells than in steroidogenic cells. The residual expression of these genes in steroidogenic cells is most probably due to contamination by endothelial cells, as it corresponded to CD31 expression (data not shown). 


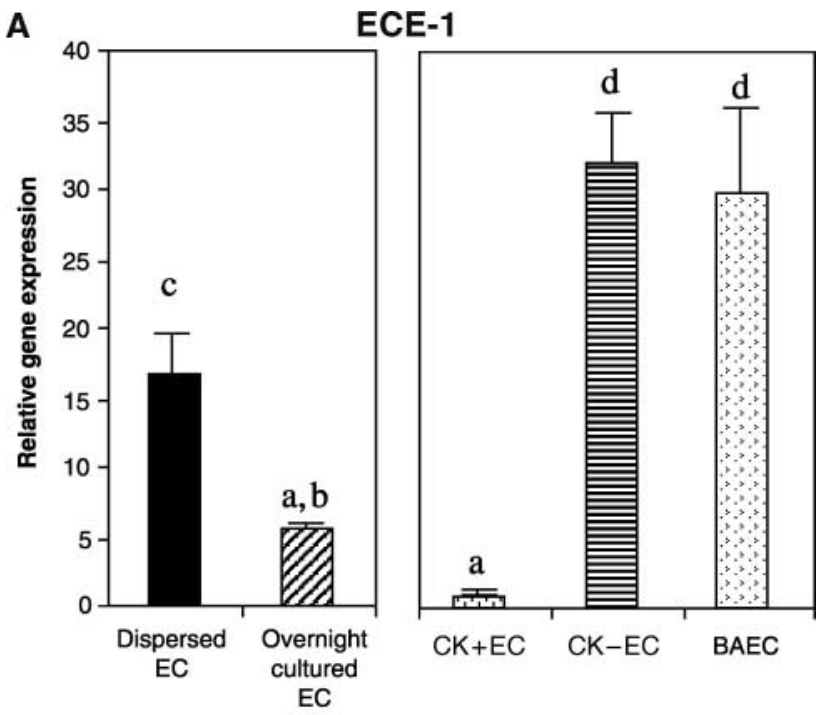

B

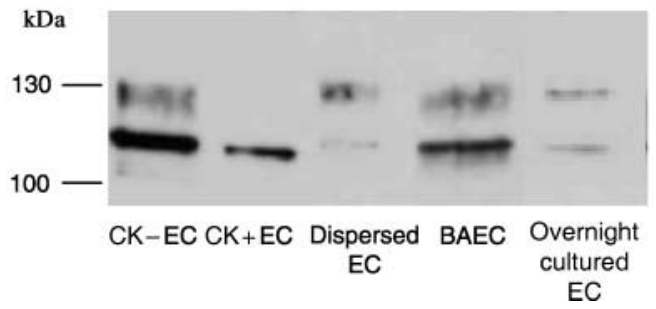

Figure 4 Total ECE-1 expression ( $m R N A$ in $A$ and protein in $B$ ) in dispersed and overnight cultured luteal EC, CK+EC, CK-EC and BAEC. PCR results of ECE-1 are the means \pm S.E.M. from four different experiments. For details see legend to Fig. 2. Different letters indicate significant differences among cell types $(P<0.05)$. (B) ECE-1 protein levels were determined by Western blot analysis using a specific C-terminal antibody. Data are the means \pm S.E.M. from three different experiments.

\section{Discussion}

The present study characterized and quantified the expression of members of the ET-1 system and NOS isoforms in corpus luteum-derived microvascular endothelial cells. By comparing the expression of these genes in cells freshly isolated from the corpus luteum with luteal endothelial cells maintained in culture (overnight or for a longterm culture) and with endothelial cells of a large blood vessel (BAEC), a typical phenotype of freshly isolated luteal endothelial cells can be described. These cells exhibited high ET-1 receptor expression (both $\mathrm{ET}_{\mathrm{A}}$ and $\mathrm{ET}_{\mathrm{B}}$ ), low ET-1 synthesizing ability (both ppET-1 and ECE1 ), and elevated iNOS - the high throughput NOS isoform. This phenotype is most probably the combined result of the endocrine and cellular microenvironment present in the corpus luteum.

The relative levels of the NO and ET-1 generating systems in luteal endothelial cells are physiologically significant, as both compounds have been ascribed key roles in the control of steroidogenesis and in the process of corpus luteum regression in several mammalian species (Apa et al. 1998, Friden et al. 2000, Skarzynski \& Okuda 2000, Hinckley \& Milvae 2001, Meidan \& Levy 2002, Tognetti et al. 2003). Additionally, as demonstrated in this study, luteal endothelial cells are the predominant site of ppET-1 and NOS mRNA expression, therefore levels found in endothelial cells are indicative of tissue levels. Indeed, our findings in endothelial cells are corroborated by data available on iNOS and ET-1 in corpora lutea of mid cycle (Girsh et al. 1996, Milvae 2000, Skarzynski et al. 2003). Of particular interest are the inverse relationship between ppET-1 and iNOS observed here. Freshly isolated cells had high iNOS and low ppET-1, while during culture iNOS was progressively reduced with ppET-1 levels simultaneously increasing. These findings suggest that ET-1 and $\mathrm{NO}$ may interact at the level of luteal endothelial cells to modulate the production of each other; however, the mechanism for such mutual regulation awaits further research. An inverse relationship between ppET-1 and iNOS expression was also observed in a recent study which demonstrated an inhibition of iNOS mRNA in bovine corpus luteum during luteolysis at the time of the expected up-regulation in ppET-1 (Neuvians et al. 2004). The compound(s) emanating from the corpus luteum milieu which is responsible for the elevated iNOS expression in freshly isolated endothelial cells is at present unknown. Yet, the fact that iNOS is already elevated in luteal tissue at the mid-late luteal phase (Skarzynski et al. 2003) and in endothelial cells of mid cycle (this study) when ET-1 expression is still low (Girsh et al. 1996, Milvae 2000, Levy et al. 2003 and this study) may suggest that $\mathrm{NO}$ regulates steady state luteal function. ET- 1 , in contrast, is not elevated until luteolysis commences (Girsh et al. 1996, Hinckley \& Milvae 2001) and therefore would be expected to act mainly during luteolysis.

ET-1 and NO function as mutual antagonists in the determination of arterial vascular tone, but are known to modulate various other physiological processes (Mawji \& Marsden 2003). Imbalances in the endothelial NO and ET-1 are therefore of potential importance beyond the acute regulation of vascular tone in large blood vessels and definitely so in the microvascular circulation such as is present in the corpus luteum, where they can serve other functions as well.

We found that ppET-1 was low in dispersed endothelial cells and increased rapidly during an overnight culture suggesting that the surrounding luteal tissue may be involved in this phenomenon. Progesterone was shown to inhibit ET-1 gene expression in endothelial cells (Morey et al. 1998), therefore the increment in ppET-1 during culture could represent an alleviation from the high progesterone milieu prevailing in the corpus luteum. If ET- 1 peptide is concomitantly elevated, it may cause the reduction of ECE-1 levels as observed previously for luteal regression - when high levels of ET-1 are present, ECE-1 levels decrease (Levy et al. 2003). 

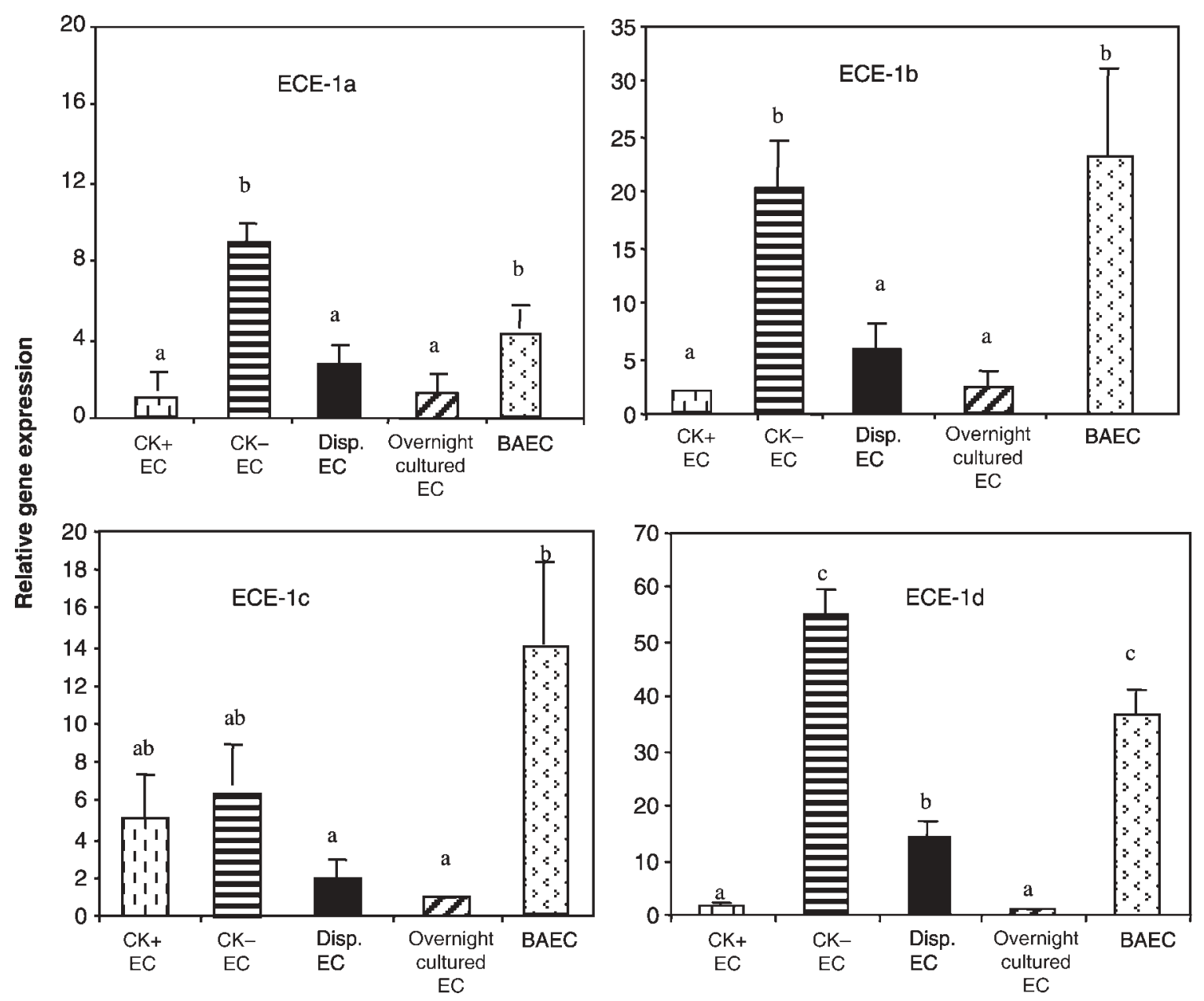

Figure 5 Pattern of mRNA expression of each ECE-1 isoform (ECE-1a, -1b, -1c and -1d) in different endothelial cell types. For details see legend to Fig. 2. Data are the means \pm S.E.M. from four different experiments. Different letters indicate significant differences among cell types $(P<0.05)$.

One of the most notable characteristics of freshly dispersed luteal endothelial cells was their high levels of both $\mathrm{ET}_{\mathrm{A}}$ and $\mathrm{ET}_{\mathrm{B}}$ receptors. These receptors were detected at the $\mathrm{mRNA}$ and protein levels. The presence of $\mathrm{ET}_{\mathrm{A}}$ in luteal endothelial cells was also demonstrated in one of our previous reports (Mamluk et al. 1999). Although the presence of pericytes or smooth muscle cells in the endothelial cell fraction was not ruled out, the fact that two different separation methods, i.e lectin-coated magnetic beads (this study) and elutriation (Mamluk et al. 1999), were utilized for the enrichment of endothelial cells strengthen these findings. Conventionally, $\mathrm{ET}_{\mathrm{A}}$ receptors are found on vascular smooth muscle cells and are responsible for the direct contractile effects of ET-1 (Luscher \& Wenzel 1995, Greenberg 2002). Therefore, the presence of $\mathrm{ET}_{\mathrm{A}}$ on luteal endothelial cells is rather unusual, although other microvascular cells (cardiac capillaries) were also reported to express $\mathrm{ET}_{\mathrm{A}}$ receptors (Wendel Wellner et al. 2002). These receptors may be involved in microvascular permeability (Filep et al. 1993) or may modulate ET-1 production and action as suggested by the findings reported here. This study also shows comparably high levels of $\mathrm{ET}_{\mathrm{B}}$ expression in freshly isolated luteal endothelial cells. These receptors are expressed in the vascular smooth muscle cells and endothelium of various tissues (Tsukahara et al. 1994, Noiri et al. 1997). In addition, it was suggested that endothelial $\mathrm{ET}_{\mathrm{B}}$ receptors are involved in the release of $\mathrm{NO}$, thereby altering peripheral vasodilation (Liu et al. 2003).

Neither $\mathrm{ET}_{\mathrm{A}}$ nor $\mathrm{ET}_{\mathrm{B}}$ receptors were maintained in longterm cultured cells and an overnight incubation of isolated endothelial cells was sufficient to significantly reduce their levels. A further decline was observed in luteal endothelial cells kept in long-term cultures; however, these cells retained some low ET receptor expression. BAEC, on the other hand, expressed none of these receptors, either at the mRNA or protein level.

Several subpopulations of mechanically released endothelial cells derived from bovine corpus luteum were characterized by Spanel-Borowski and co-workers (Spanel Borowski \& van der Bosch 1990, Spanel Borowski \& Fenyves 1994). While CK- cells derive from the typical, predominant endothelial cell population in the bovine 


\section{iNOS}

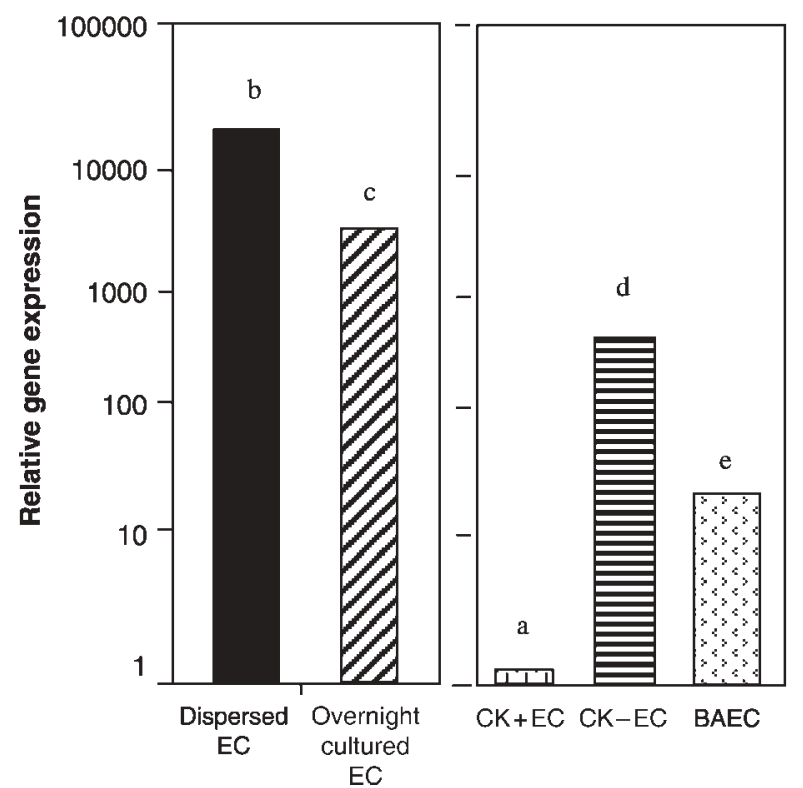

eNOS

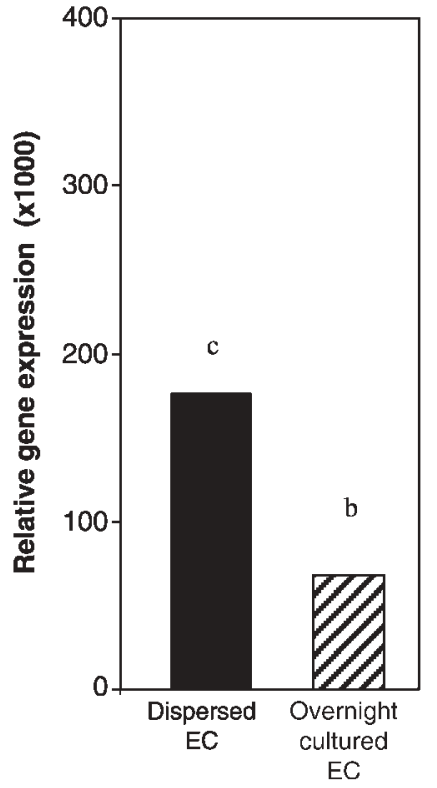

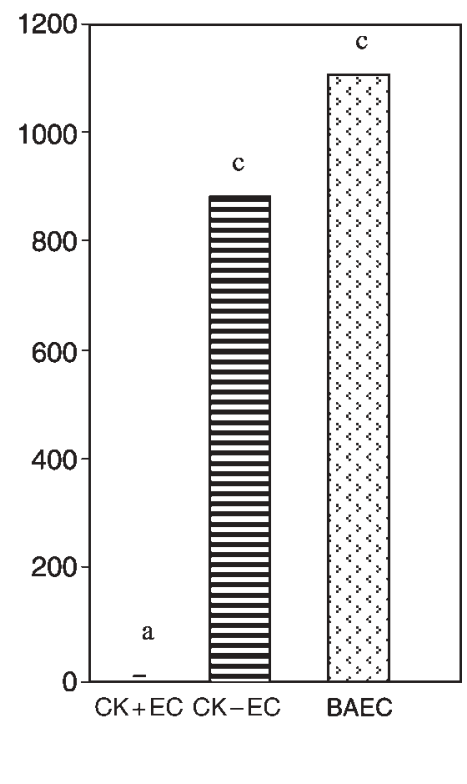

Figure 6 The relative distribution of NOS isoforms mRNA expression within each endothelial cell type. Data are the means \pm S.E.M. from four different experiments. For details see legend to Fig. 2. Different letters indicate significant differences among cell types $(P<0.05)$. Error bars were too small to be depicted.

corpus luteum, CK + cells comprise a rare luteal endothelial cell type. Data obtained in this study further confirm that CK + cells are atypical endothelial cells, as their expression of most genes examined was considerably lower than in the CK- cells.

Although both ppET-1 and ECE-1 act in concert to produce the bioactive peptide, these genes are controlled independently. Previously, this has been shown to occur in a tissue (Tripiciano et al. 1999, Levy et al. 2001) (where more than one cell type can express the genes); this study now shows that ET-1 and ECE- 1 can also be differently regulated within the same cell. All four ECE-1 isoforms were expressed by the different endothelial cells utilized in this study, although there was a distinct distribution of
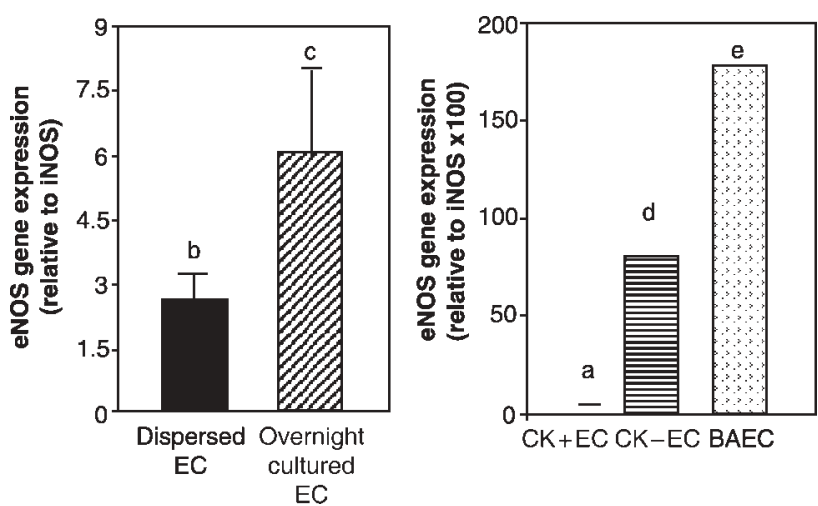

Figure 7 The expression of eNOS relative to iNOS mRNA expression in the different endothelial cell types. Data are the means \pm S.E.M. from four different experiments. Expression is presented as relative gene expression using iNOS of each cell type as calibrator. Different letters indicate significant differences among cell types $(P<0.05)$. each isoform in the different cell types. The diverse amino-terminal sequences in the different isoforms directs tissue-specific expression, as well as different subcellular localization (Emoto et al. 1999, Tripiciano et al. 1999, Valdenaire et al. 1999a, Levy et al. 2003). Therefore, the identification of ECE-1 isoform distribution in luteal endothelial cells could elucidate the site of big ET-1 cleavage. The high levels of ECE-1d in luteal endothelial cells reported here favor an intracellular site of ET-1 activation (Muller et al. 2003).

Endothelial cells from different tissues display diverse characteristics imposed by their tissue microenvironment (LeCouter et al. 2002, Chi et al. 2003). One of the well known examples is the effect of astrocytes on the ability of brain endothelial cells to exhibit barrier properties (Descamps et al. 1996). We observed here that freshly isolated luteal endothelial cells have a characteristic gene expression profile for almost all members of the ET-1 system as well as for the two NOS isoforms. When removed from the corpus luteum microenvironment, endothelial cells gradually lose some of their selective characteristics. Nevertheless, some differences in gene expression remain

Table 3 Relative levels of mRNA expression of NOS isoforms and ppET-1 in freshly isolated luteal steroidogenic and endothelial cells. Data are the means \pm S.D. ( $n=5$ separate CL preparations).

\begin{tabular}{lcrr}
\hline & \multicolumn{1}{c}{ iNOS } & \multicolumn{1}{c}{ eNOS } & \multicolumn{1}{c}{ ppET-1 } \\
\hline Steroidogenic cells & $0.14 \pm 0.07$ & $0.3 \pm 0.26$ & $0.47 \pm 0.11$ \\
Endothelial cells & $8.56 \pm 4.17$ & $26.79 \pm 8.50$ & $14.67 \pm 3.11$
\end{tabular}

The relative expression for each gene was calculated using the $\Delta C_{t}$ method (see Materials and Methods). 
even in the long-term cultured cells: ECE-1C, $\mathrm{ET}_{\mathrm{B}}$ receptors and NOS isoforms were expressed differently in BAEC as compared with luteal endothelial cell lines. Recently, we have also noted that type II receptors of a novel pro-angiogenic factor, endocrine gland-vascular endothelial growth factor/prokineticin 1 (Kisliouk et al. 2003), are present in fresh and cultured luteal endothelial cells but absent in BAEC. These data highlight the intrinsic properties of endothelial cells originating from the corpus luteum.

The profile of gene expression in corpus luteum-derived endothelial cells described here will contribute to a better appreciation of the distinct characteristics in these cells. Such knowledge is mandatory for the design of novel approaches to control the function of the corpus luteum and perhaps other steroidogenic tissues as well.

\section{Acknowledgements}

This study was supported by a grant from the Bi-national Agricultural Research and Development Foundation (BARD).

\section{References}

Albrecht EW, Stegeman CA, Heeringa P, Henning RH \& van Goor H 2003 Protective role of endothelial nitric oxide synthase. Journal of Pathology 199 8-17.

Alderton WK, Cooper CE \& Knowles RG 2001 Nitric oxide synthases: structure, function and inhibition. Biochemical Journal $357593-615$.

Apa R, Miceli F, de Feo D, Pierro E, Ayala G, Mancuso S, Napolitano M \& Lanzone A 1998 Endothelin-1: expression and role in human corpus luteum. American Journal of Reproductive Immunology $\mathbf{4 0}$ 370-376.

Arai H, Hori S, Aramori I, Ohkubo H \& Nakanishi S 1990 Cloning and expression of a cDNA encoding an endothelin receptor. Nature 348 730-732.

Aramori I \& Nakanishi S 1992 Coupling of two endothelin receptor subtypes to differing signal transduction in transfected Chinese hamster ovary cells. Journal of Biological Chemistry 267 $12468-12474$.

Chi JT, Chang HY, Haraldsen G, Jahnsen FL, Troyanskaya OG, Chang DS, Wang Z, Rockson SG, van de Rijn M \& Botstein D 2003 Endothelial cell diversity revealed by global expression profiling. PNAS 100 10623-10628.

Descamps L, Dehouck MP, Torpier G \& Cecchelli R 1996 Receptormediated transcytosis of transferrin through blood-brain barrier endothelial cells. American Journal of Physiology $\mathbf{2 7 0}$ H1149-H1158.

Emoto N, Nurhantari Y, Alimsardjono H, Xie J, Yamada T, Yanagisawa M \& Matsuo M 1999 Constitutive lysosomal targeting and degradation of bovine endothelin-converting enzyme-1a mediated by novel signals in its alternatively spliced cytoplasmic tail. Journal of Biological Chemistry 274 1509-1518.

Fields MJ \& Fields PA 1996 Morphological characteristics of the bovine corpus luteum during the estrous cycle and pregnancy. Theriogenology 45 1295-1325.

Filep JG, Sirois MG, Foldes Filep E, Rousseau A, Plante GE, Fournier A, Yano M \& Sirois P 1993 Enhancement by endothelin-1 of microvascular permeability via the activation of ETA receptors. British Journal of Pharmacology 109 880-886.

Friden BE, Runesson E, Hahlin M \& Brannstrom M 2000 Evidence for nitric oxide acting as a luteolytic factor in the human corpus luteum. Molecular Human Reproduction 6 397-403.
Girsh E, Wang W, Mamluk R, Arditi F, Friedman A, Milvea RA \& Meidan R 1996 Regulation of endothelin-1 expression in the bovine corpus luteum: elevation by prostaglandin $\mathrm{F}_{2 \alpha}$. Endocrinology $1375191-5196$.

Grazul Bilska AT, Redmer DA \& Reynolds LP 1997 Cellular interactions in the corpus luteum. Seminars in Reproductive Endocrinology 15 383-393.

Greenberg BH 2002 Endothelin and endothelin receptor antagonists in heart failure. Congestive Heart Failure 8 257-261.

Hinckley ST \& Milvae RA 2001 Endothelin-1 mediates prostaglandin $\mathrm{F}$ (2alpha)-induced luteal regression in the ewe. Biology of Reproduction 64 1619-1623.

Jaroszewski JJ \& Hansel W 2000 Intraluteal administration of a nitric oxide synthase blocker stimulates progesterone and oxytocin secretion and prolongs the life span of the bovine corpus luteum. Proceedings of the Society for Experimental Biology and Medicine 224 50-55.

Kisliouk T, Levy N, Hurwitz A \& Meidan R 2003 Presence and regulation of endocrine gland vascular endothelial growth factor/prokineticin-1 and its receptors in ovarian cells. Journal of Clinical Endocrinology and Metabolism 88 3700-3707.

LeCouter J, Lin R \& Ferrara N 2002 Endocrine gland-derived VEGF and the emerging hypothesis of organ-specific regulation of angiogenesis. Nature Medicine 8 913-917.

Lehmann I, Brylla E, Sittig D, Spanel Borowski K \& Aust G 2000 Microvascular endothelial cells differ in their basal and tumour necrosis factor-alpha-regulated expression of adhesion molecules and cytokines. Journal of Vascular Research 37 408-416.

Levy N, Gordin M, Mamluk R, Yanagisawa M, Smith MF, Hampton JH \& Meidan R 2001 Distinct cellular localization and regulation of endothelin-1 and endothelin-converting enzyme-1 expression in the bovine corpus luteum: implications for luteolysis. Endocrinology $1425254-5260$.

Levy N, Gordin M, Smith MF, Bolden-Tiller OU \& Meidan R 2003 Hormonal regulation and cell-specific expression of endothelin converting enzyme- 1 isoforms in bovine ovarian endothelial and steroidogenic cells. Biology of Reproduction $\mathbf{6 8}$ 1361-1368.

Liu S, Premont RT, Kontos CD, Huang J \& Rockey DC 2003 Endothelin-1 activates endothelial cell nitric-oxide synthase via heterotrimeric G-protein betagamma subunit signaling to protein kinase B/Akt. Journal of Biological Chemistry 278 49929-49935.

Livak KJ \& Schmittgen TD 2001 Analysis of relative gene expression data using real-time quantitative PCR and the 2(-delta delta $\mathrm{C}(\mathrm{T})$ ) method. Methods 25 402-408.

Luscher TF \& Wenzel RR 1995 Endothelin and endothelin antagonists: pharmacology and clinical implications. Agents and Actions. Supplements 45 237-253.

Mamluk R, Levy N, Rueda B, Davis JS \& Meidan R 1999 Characterization and regulation of type $\mathrm{A}$ endothelin receptor gene expression in bovine luteal cell types. Endocrinology 40 2110-2116.

Mawji IA \& Marsden PA 2003 Perturbations in paracrine control of the circulation: role of the endothelial-derived vasomediators, endothelin-1 and nitric oxide. Microscopy Research and Technique 60 46-58.

Meidan R \& Levy N 2002 Endothelin-1 receptors and biosynthesis in the corpus luteum: molecular and physiological implications. Domestic Animal Endocrinology 23 287-298.

Meidan R, Milvae RA, Weiss S, Levy N \& Friedman A 1999 Intraovarian regulation of luteolysis. Journal of Reproduction and Fertility 54 217-228.

Milvae RA 2000 Inter-relationships between endothelin and prostaglandin F2alpha in corpus luteum function. Reviews of Reproduction 5 1-5.

Miyamoto A, Kobayashi S, Arata S, Ohtani M, Fukui Y \& Schams D 1997 Prostaglandin $F_{2 \alpha}$ promotes the inhibitory effects of endothelin-1 on the bovine luteal function in vitro. Journal of Endocrinology 152 R7-R11. 
Morey AK, Razandi M, Pedram A, Hu RM, Prins BA \& Levin ER 1998 Oestrogen and progesterone inhibit the stimulated production of endothelin-1. Biochemical Journal 330 1097-1105.

Muller L, Barret A, Etienne E, Meidan R, Valdenaire O, Corvol P \& Tougard C 2003 Heterodimerization of endothelin-converting enzyme-1 isoforms regulates the subcellular distribution of this metalloprotease. Journal of Biological Chemistry 278 545-555.

Neuvians TP, Schams D, Berisha B \& Pfaffl MW 2004 Involvement of pro-inflammatory cytokines, mediators of inflammation and basic fibroblast growth factor in prostaglandin F2alpha-induced luteolysis in bovine corpus luteum. Biology of Reproduction $\mathbf{7 0}$ 473-480.

Neylon CB 1999 Vascular biology of endothelin signal transduction. Clinical and Experimental Pharmacology and Physiology 26 149-153.

Noiri E, Hu Y, Bahou WF, Keese CR, Giaever I \& Goligorsky MS 1997 Permissive role of nitric oxide in endothelin-induced migration of endothelial cells. Journal of Biological Chemistry 272 1747-1752.

Okada K, Miyazaki Y, Takada J, Matsuyama K, Yamaki T \& Yano M 1990 Conversion of big endothelin-1 by membrane-bound metalloendopeptidase in cultured bovine endothelial cells. Biochemical and Biophysical Research Communications. 171 1192-1198.

Reynolds LP, Grazul Bilska AT \& Redmer DA 2000 Angiogenesis in the corpus luteum. Endocrine 12 1-9.

Schmidt M, Kroger B, Jacob E, Seulberger H, Subkowski T, Otter R, Meyer T, Schmalzing G \& Hillen H 1994 Molecular characterization of human and bovine endothelin converting enzyme (ECE-1). FEBS Letters 356 238-243.

Schweizer A, Valdenaire O, Nelbock P, Deuschle U, Dumas Milne Edwards JB, Stumpf JG \& Loffler BM 1997 Human endothelinconverting enzyme (ECE-1): three isoforms with distinct subcellular localizations. Biochemical Journal 328 871-877.

Skarzynski DJ \& Okuda K 2000 Different actions of noradrenaline and nitric oxide on the output of prostaglandins and progesterone in cultured bovine luteal cells. Prostaglandins and Other Lipid Mediators $6035-47$.

Skarzynski DJ, Jaroszewski JJ, Bah MM, Deptula KM, Barszczewska B, Gawronska B \& Hansel W 2003 Administration of a nitric oxide synthase inhibitor counteracts prostaglandin F2-induced luteolysis in cattle. Biology of Reproduction 68 1674-1681.

Spanel Borowski K \& van der Bosch J 1990 Different phenotypes of cultured microvessel endothelial cells obtained from bovine corpus luteum. Study by light microscopy and by scanning electron microscopy (SEM). Cell and Tissue Research 261 35-47.

Spanel Borowski K \& Bein G 1993 Different microvascular endothelial cell phenotypes exhibit different class I and II antigens under interferon-gamma. In Vitro Cellular and Developmental Biology - Animal 29a 601-602.
Spanel Borowski K \& Fenyves A 1994 The heteromorphology of cultured microvascular endothelial cells. Arzneimittelforschung $\mathbf{4 4}$ 385-391.

Tognetti T, Estevez A, Luchetti CG, Sander V, Franchi AM \& Motta AB 2003 Relationship between endothelin 1 and nitric oxide system in the corpus luteum regression. Prostaglandins, Leukotrienes and Essential Fatty Acids 69 359-364.

Tripiciano A, Peluso C, Morena AR, Palombi F, Stefanini M, Ziparo E, Yanagisawa M \& Filippini A 1999 Cyclic expression of endothelin-converting enzyme-1 mediates the functional regulation of seminiferous tubule contraction. Journal of Cellular Biology $\mathbf{1 4 5}$ 1027-1038.

Tsukahara H, Ende H, Magazine HI, Bahou WF \& Goligorsky MS 1994 Molecular and functional characterization of the non-isopeptide-selective ETB receptor in endothelial cells. Receptor coupling to nitric oxide synthase. Journal of Biological Chemistry 269 $21778-21785$.

Turner AJ, Barnes K, Schweizer A \& Valdenaire O 1998 Isoforms of endothelin-converting enzyme: why and where? Trends in Pharmacological Sciences $19483-486$

Valdenaire $O$, Barret A, Schweizer A, Rohrbacher E, Mongiat F, Pinet F, Corvol P \& Tougard C 1999a Two di-leucine-based motifs account for the different subcellular localizations of the human endothelin-converting enzyme (ECE-1) isoforms. Journal of Cell Science 112 3115-3125.

Valdenaire O, Lepailleur ED, Egidy G, Thouard A, Barret A, Vranckx R, Tougard C \& Michel Jean B 1999b A fourth isoform of endothelin-converting enzyme (ECE-1) is generated from an additional promoter: molecular cloning and characterization. European Journal of Biochemistry 264 341-349.

Wendel Wellner M, Noll T, Konig P, Schmeck J, Koch T \& Kummer W 2002 Cellular localization of the endothelin receptor subtypes $\mathrm{ET}(\mathrm{A})$ and $\mathrm{ET}(\mathrm{B})$ in the rat heart and their differential expression in coronary arteries, veins, and capillaries. Histochemistry and Cell Biology 118 361-369.

Wright MF, Sayre B, Keith Inskeep EK \& Flores JA 2001 Prostaglandin $\mathrm{F}$ (2alpha) regulation of the bovine corpus luteum endothelin system during the early and midluteal phase. Biology of Reproduction 65 1710-1717.

Xu D, Emoto N, Giaid A, Slaughter C, Kaw S, deWit D \& Yanagisawa M 1994 ECE-1: a membrane-bound metalloprotease that catalyzes the proteolytic activation of big endothelin-1. Cell 78 473-485.

Received 5 April 2004

First decision 26 May 2004

Revised manuscript received 21 June 2004

Accepted 2 July 2004 